\title{
Biological Characteristics and Tissue Structure of a Crustose Coralline Lithophyllum Alga
}

\author{
Ji-Young Kang', lanthe Marie P. Benliro ${ }^{2}$, Ik-Joon Lee', Ji-Young Choi', Jin Joo ${ }^{3}$, Yoo Seong Choi ${ }^{4}$, \\ Dong Soo Hwang ${ }^{5}$ and Yong-Ki Hong ${ }^{1,2}$ * \\ ${ }^{1}$ Department of Biotechnology, ${ }^{2}$ KOICA-PKNU International Graduate Program of Fisheries Science, Pukyong National University, Namku, \\ Busan 608-737, Korea \\ ${ }^{3}$ Department of Applied Chemistry, Kyungpook National University, Daegu 702-701, Korea \\ ${ }^{4}$ Department of Chemical Engineering, Chungnam National University, Dagieon 305-764, Korea \\ ${ }^{5}$ Postech Ocean Science \& Technology Institute, Pohang University of Science \& Technology, Pohang 790-784, Korea
}

Received January 24, 2013 /Revised March 6, 2013 /Accepted March 11, 2013

\begin{abstract}
The disappearance of seaweed flora in some rocky areas, which is known as algal whitening, barren ground, coralline flats, or deforested areas, is associated with some species of coralline algae. To determine the biological characteristics of a representative species of crustose coralline alga, the $18 \mathrm{~S}$ rDNA gene was sequenced to identify the genus Lithophyllum According to its morphological and distributional characteristics, it was deduced to be L yessoense. Viability was measured using triphenyl tetrazolium chloride and showed high viability from December to February. Culture conditions of $16^{\circ} \mathrm{C}$, a $16 \mathrm{hr}$ light, $8 \mathrm{hr}$ dark cycle, and $30 \mu \mathrm{E} / \mathrm{m}^{2} / \mathrm{s}$ light intensity were optimal for maintaining the viability of the alga for up to five days. Included in the fatty acids was $9.7 \% \omega-3$ eicosapentaenoic acid. An electron microscopy scan of the surface structure revealed round craters about $3.6 \mu \mathrm{m}$ in diameter, which were covered with rough, irregular, and angular polygon-shaped structures about 1.0 to $3.7 \mu \mathrm{m}$ in size. Based on the composition and structure found in our study, biomimetic coralline alga might become an environmentally friendly antifouling material against the attachment of soft foulants.
\end{abstract}

Key words : Crustose alga, fatty acid, Lithophyllum, tissue structure, viability

\section{Introduction}

Seaweeds play a major role in marine ecosystems. They provide nutrients for animals - either directly when fronds are eaten, or indirectly when decomposing parts break down into fine particles and are taken up by filter-feeding animals. Beds of seaweed provide shelter and habitat for scores of coastal animals for all or part of their lives. Coralline red algae, both of crustose (nongeniculate) and articulated corallines, abound in intertidal rocky shore areas and strongly influence the benthic community. Crustose coralline algae are a major calcifying component of the marine benthos from tropical to polar oceans at all depths within the photic zone [20]. When the coralline algae are growing, the rock surfaces

\section{*Corresponding author}

Tel : +82-51-629-5862, Fax : +82-51-629-5863

E-mail : ykhong@pknu.ac.kr

This is an Open-Access article distributed under the terms of the Creative Commons Attribution Non-Commercial License (http://creativecommons.org/licenses/by-nc/3.0) which permits unrestricted non-commercial use, distribution, and reproduction in any medium, provided the original work is properly cited. appear pink, while the fleshy seaweed flora disappears from the rocky areas. In marine environments, this phenomenon is generally called algal whitening, barren ground [22], coralline flats, or deforested areas. It is now recognized as a natural hazard adversely affecting marine ecosystems and damaging commercial fishing areas. Although biological [2, 11, $23]$ and physical $[8,15]$ factors may be sufficient to prevent the recruitment of fleshy seaweeds, allelopathic bromoform $[16]$ and fatty acid $[10,14]$ substances may also inhibit the settlement or germination of seaweed spores. Consequently, coralline algae may prevent fouling by fleshy seaweeds. Alternatively, biomimetic coralline alga material might become an environmentally friendly antifouling material. In nature, most coralline algae are pink and have almost indistinguishable shapes, those causes confusion in their identification. Therefore, in an attempt to make a biomimetic coralline alga material, we have to identify the species, select the best conditioned tissues as standard material, analyze the fatty acid composition, and observe the fine surface structure. 


\section{Materials and Methods}

\section{Plant material}

Crustose coralline algae were collected monthly from the rocky intertidal area at Cheongsapo $\left(35^{\circ} 09^{\prime} 28^{\prime \prime} \mathrm{N}, 129^{\circ} 11^{\prime} 47^{\prime \prime}\right.$ E), on the east coast of Busan, Korea. The samples were transported in a container with seawater to the laboratory. After rinsing well with autoclaved seawater to remove epiphytes and debris, the encrusted tissues were sonicated three times with 30-s pulses of an ultrasonic water bath (low-intensity frequency of $90 \mathrm{kHz}$ ) to remove other microepiphytes.

\section{Molecular identification}

Approximately $0.2 \mathrm{~g}$ of the coralline alga was chopped into very tiny pieces and placed in a microtube. DNA was extracted using $\mathrm{LiCl}$, following Hong et al. [7]. The $18 \mathrm{~S}$ rDNA gene, encoding the ribosomal RNA in the small subunit of eukaryotic cytoplasmic ribosome, was amplified by polymerase chain reaction (PCR) with the universal primers $18 \mathrm{sF}$ (5'CAACCTGGTTGATCCTGCCAGT3') and 18sR (5'GATCCTTCTGCAGGTTCACCTACGGAA3') [4]. The PCR cycling parameters consisted of $94^{\circ} \mathrm{C}$ for $5 \mathrm{~min}, 30 \mathrm{cy}$ cles of $94^{\circ} \mathrm{C}$ for $30 \mathrm{sec}, 57^{\circ} \mathrm{C}$ for $30 \mathrm{sec}, 72^{\circ} \mathrm{C}$ for $1.5 \mathrm{~min}$, and a final $72^{\circ} \mathrm{C}$ for $10 \mathrm{~min}$. The amplification products were sequenced using the same primers (SolGent, Daejeon, Korea). The sequences were edited and manipulated using MEGA3 [12]. Phylogenetic trees were inferred using the neighbor-joining algorithm [19] in MEGA3 with bootstrap analysis of 1,000 bootstrap replications.

\section{Viability assay}

To measure the viability of the coralline tissue, the assay of Park et al. [17] was used. Briefly, $1 \mathrm{ml}$ of $0.8 \%$ 2,3,5-triphenyltetrazolium chloride (TTC) in seawater containing 50 $\mathrm{mM}$ Tris- $\mathrm{HCl}$ buffer ( $\mathrm{pH}$ 8.0) was added to $50 \mathrm{mg}$ of tissue in a 1.5-ml microtube and incubated in darkness for $1.5 \mathrm{hr}$ at $20^{\circ} \mathrm{C}$ under mineral oil. The triphenyl formazan that formed in the tissue was extracted with $0.6 \mathrm{ml}$ of $0.2 \mathrm{~N}$ $\mathrm{KOH}$ in $75 \%$ ethanol by heating for $15 \mathrm{~min}$ at $60^{\circ} \mathrm{C}$. The triphenyl formazan was quantified by measuring the absorbance at $475 \mathrm{~nm}$. To determine the optimal conditions for maintaining viability, $0.25 \mathrm{~g}$ of the tissue was cultured in $50 \mathrm{ml}$ of seawater under $30 \mu \mathrm{E} / \mathrm{m}^{2} / \mathrm{s}$ light intensity on a $16 \mathrm{hr}$ light: $8 \mathrm{hr}$ dark cycle at $16^{\circ} \mathrm{C}$ for 5 days as the standard conditions.

\section{Scanning electron microscopy}

Healthy tissue collected on February 9, 2012 was washed with Milli-Q water (Millipore, Billerica, MA) and dried under vacuum before scanning electron microscopy (SEM) analysis. For SEM images, tissues were mounted on conductive carbon tabs of a SEM post (Ted Pella, Inc., Redding, CA), sputter-coated using a Desk-II coater equipped with a gold target (Alfa Aesar, Ward Hill, MA), and imaged in a scanning-electron microscope (JSM-6700F; JEOL, Tokyo, Japan). To determine the elemental composition of parts of the tissues, the tissues were analyzed using energy-dispersive X-ray spectroscopy. The standards for carbon, oxygen, sodium, chlorine, and calcium were calcium carbonate, silicon dioxide, albite, potassium chloride, and wollastonite, respectively.

\section{Fatty acid analysis}

Fatty acids were determined by gas chromatographic quantification of their methyl esters (FAMEs), which were prepared using slightly modified method from the AOAC [3]. Total lipid was extracted from the dried samples using a Soxhlet extractor. Then, FAMEs were prepared with $5 \mathrm{ml}$ of methylation solution ( $1 \mathrm{H}_{2} \mathrm{SO}_{4}: 20 \mathrm{CH}_{3} \mathrm{OH}: 10$ toluene) and heated at $100^{\circ} \mathrm{C}$ for $1 \mathrm{hr}$. Gas chromatography-mass spectroscopy (GC-MS) analysis was conducted using a 6890 network GC system with a 5973N Mass Selective Detector (MSD) (Agilent Technologies, Palo Alto, CA). The oven was started at $50^{\circ} \mathrm{C}$ and held for $1 \mathrm{~min}$, and then ramped up to $320^{\circ} \mathrm{C}$ at $5^{\circ} \mathrm{C} / \mathrm{min}$. The MSD was operated based on electron ionization.

\section{Results and Discussion}

A dominant crustose coralline alga from barren grounds was pinkish to reddish and generally characterized by their encrusted calcareous composition. They typically colonized rocky substrates and formed smooth and flat crust in the intertidal area exposed to waves. It is known that many areas of the rocky shorelines of Korea and Japan are dominated by crustose coralline algae such as Lithophyllum yessoense Foslie $[9,21]$. The group's internal taxonomy is still in a state of flux; molecular studies are proving more reliable than morphological methods in approximating relationships within the group [5]. To ascertain the species identification, we determined partial 185 rDNA gene sequence (NCBI submission \# 1609660). They were then aligned and analyzed 
using the neighbor-joining method to construct a dendrogram. The 1,391-bp $18 \mathrm{~S}$ rDNA sequence from base 274 to 1,664 was compared to the sequences of 13 species of coralline algae obtained from the NCBI database to infer the phylogenetic relationship (Fig. 1). The $18 \mathrm{~S}$ rDNA sequence showed the closest to the sequence of Lithophyllum incrustans. The sequence matched 99\% homology with 15 base difference from the $L$ incrustans sequence (GenBank accession \# AF093410.1). Meanwhile, the L. incrustans is described as thick, dull chalky, yellowish, pink or lavender calcareous crusts forming irregular concretions, to $40 \mathrm{~mm}$ thick, margins ridged where crusts meet, in the AlgaeBase [6]. The alga used in this study has typically no margins ridged where crusts meet, and is not much thick, dull chalky and yellowish. Thus, the alga was identified to be belonging to the crustose coralline Lithophyllum genus using the $18 \mathrm{~S}$ rDNA sequence, but not able to confirm the species level. By the morphological shape, the crustaceous thalli spread irregularly like a pinky patch, non-verrucose on surface. It is distributed in warm current sea along the coasts of Jeju and Busan, Korea. From the morphological and distributional characteristics, it may be deduced to L. yessoense [22].

Using the TTC method, we measured the viability of crustose coralline tissues collected at the same site throughout the year (Fig. 2) and quantified viability as the absorbance at $545 \mathrm{~nm}$. The tissues collected in February had the greatest viability, which then decreased gradually in the spring and summer. Some tissues remained pinky crust, and some disappeared from the rock surface. In autumn, they started to

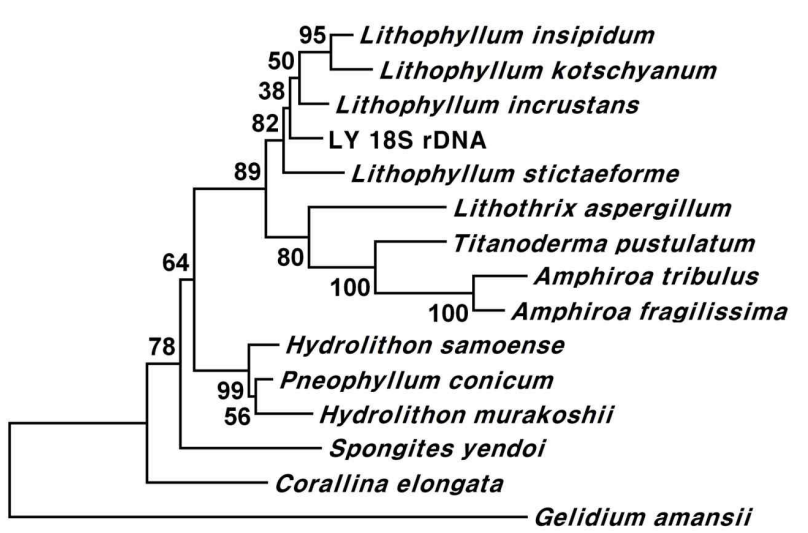

\section{$\stackrel{\longmapsto}{0.01}$}

Fig. 1. Phylogenetic dendrograms of the crustose coralline alga based on $18 \mathrm{~S}$ rDNA sequence, and constructed using the neighbor-joining method. Numbers at nodes indicate the level of bootstrap support (1,000 replicates). grow, and most tissues recovered their viability. In December and February, the tissues again had the healthiest pink structure and greatest viability. Therefore, this period would be the best season to use as a model structure of a biomimetic antifouling material. To keep healthy tissues, we optimized the maintenance conditions using the TTC viability assay (Fig. 3). The optimal temperature for incubation was $16^{\circ} \mathrm{C}$, the optimal light intensity was $30 \mu \mathrm{E} / \mathrm{m}^{2} / \mathrm{s}$ with white fluorescent light, and the optimal light period was a $16 \mathrm{hr}$ light:8 hr dark cycle. Under these conditions, the tissues maintained the best viability for up to 5 days in a standing flask containing natural seawater. Therefore, the tissues were kept at the optimized conditions and used within 5 days.

Among the factors preventing the settlement or germination of fleshy seaweed spores, we found that polyunsaturated fatty acids (PUFAs) have potent lytic activity against algal spores [14]. When preparing biomimetic coralline alga material, the antifouling activity might be enhanced by adding bioactive PUFAs. Therefore, we determined the major fatty acid composition of healthy coralline tissue (Table 1 ). Of the fatty acids, $23.4 \%$ were PUFAs, with $\omega-3$ eicosapentaenoic acid (EPA; C20:5) comprising 9.7\% and $\omega-6$ arachidonic acid (AA; C20:4) comprising 5.1\%; the $\omega-6: \omega-3$ ratio was 1.42. In the previous study [14], EPA and AA showed strong lytic activity against algal spore with $\mathrm{LC}_{50}$ $=2.1$ and $1.8 \mu \mathrm{g} / \mathrm{ml}$, respectively. Therefore, the preparation of biomimetic calcium carbonate nanoparticles with EPA and/or AA will have potent antifouling activity as an envi-

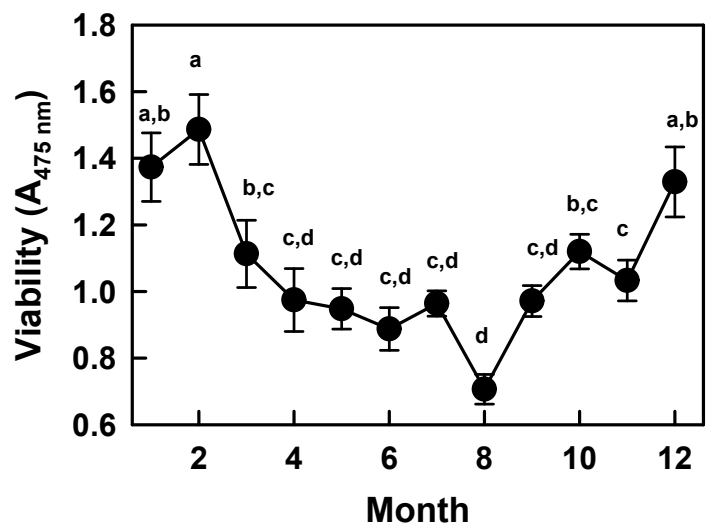

Fig. 2. Seasonal variation in the viability of the crustose coralline tissue. The viability was quantified using the absorbance at $474 \mathrm{~nm}$, and the values are the mean $\pm \mathrm{SD}$ of at least five independent assays. Mean values with different letters (a-d) are significantly different by Duncan's multiple range test $(\not<0.05)$. 

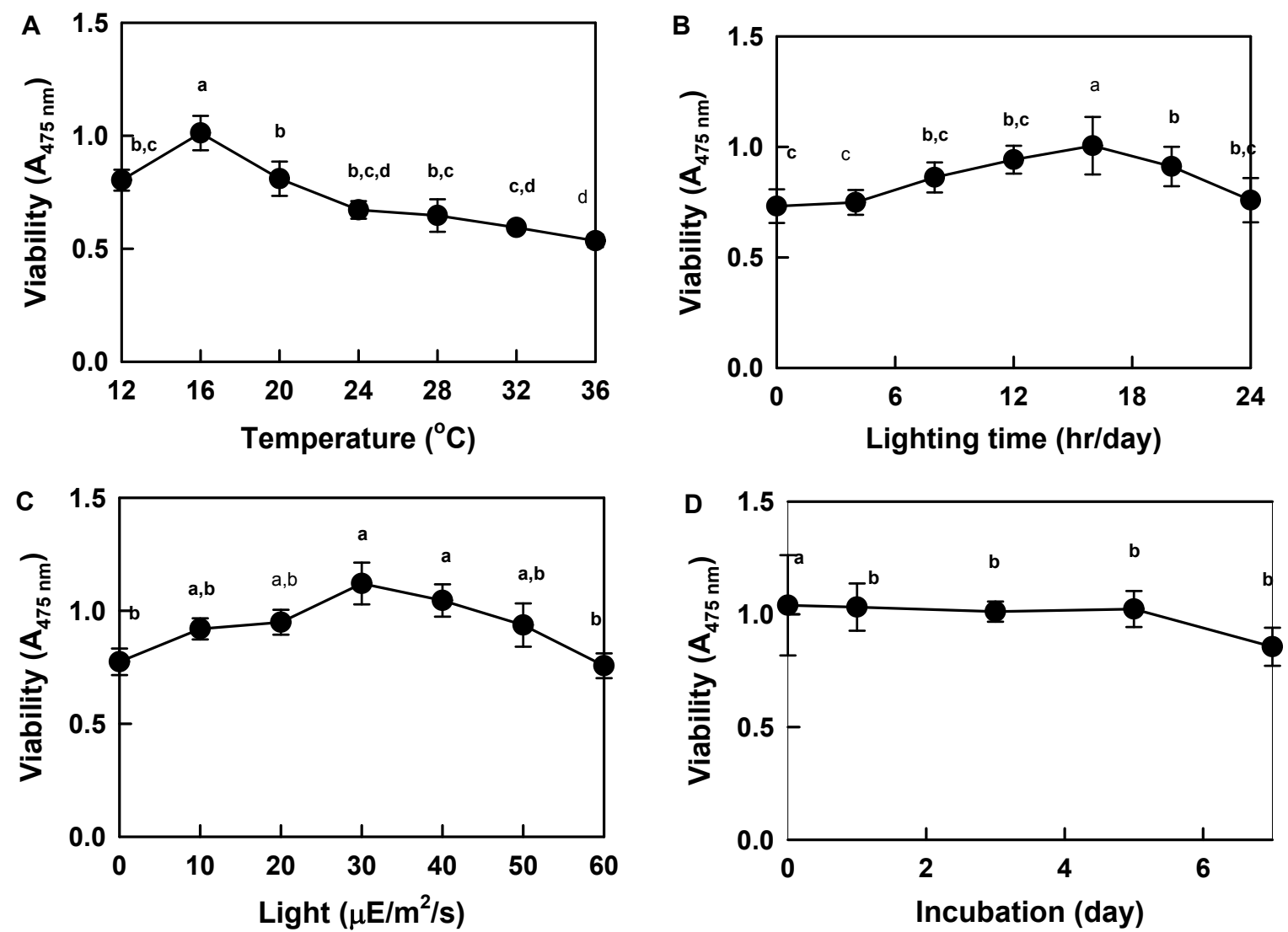

Fig. 3. Effect of various parameters on the optimal maintenance of crustose coralline tissue: (A) incubation temperature, (B) amount of light per day, (C) light intensity, and (D) incubation period under the optimized conditions. The viability was measured using the absorbance at $474 \mathrm{~nm}$, and the values are expressed as the mean $\pm \mathrm{SD}$ of at least five independent assays. Mean values with different letters $(\mathrm{a}-\mathrm{d})$ are significantly different by Duncan's multiple range test $(p<0.05)$.

Table 1. Profile of the major fatty acids (\% of total fatty acids) in the crustose coralline tissue collected on February 9, 2012

\begin{tabular}{lc}
\hline Fatty acids & Relative amount $(\%)$ \\
\hline $\mathrm{C} 16: 0$ & 36.9 \\
$\mathrm{C} 18: 0$ & 11.6 \\
$\mathrm{C} 18: 1 \omega-9$ & 1.2 \\
$\mathrm{C} 18: 2 \omega-6$ & 3.2 \\
$\mathrm{C} 18: 3 \omega-6$ & 1.5 \\
$\mathrm{C} 20: 0$ & 1.7 \\
$\mathrm{C} 20: 4 \omega-6$ & 5.1 \\
$\mathrm{C} 20: 5 \omega-3$ & 9.7 \\
$\mathrm{C} 22: 0$ & 11.4 \\
$\mathrm{C} 22: 2 \omega-6$ & 3.2 \\
C24:0 & 3.3 \\
Saturated fatty acids & 74.0 \\
MUFAs & 2.6 \\
PUFAs & 23.4 \\
\hline
\end{tabular}

ronmentally friendly bio-control.

The surface structure of the crustose coralline tissue was examined using SEM. The tissue surface was covered with round craters about 2.5 to $5.0 \mu \mathrm{m}$ in diameter at the surface (Fig. 4A). Most of these crater-shaped structures were irregular circles of average $3.6 \mu \mathrm{m}$ in diameter. The upper rough tissue was covered with irregular and angular polygon-shaped structures about 1.0 to $3.7 \mu \mathrm{m}$ in size (Fig. $4 \mathrm{~B})$. The average is about $2.1 \mu \mathrm{m}$ in size. Some corallines slough off a surface layer of epithallial cells, which in a few cases may be an antifouling mechanism which serves the same function as enhancing herbivore recruitment $[8,15]$. This also affects the community, as many algae recruit on the surface of a sloughing coralline, and are then lost with the surface layer of cells. This can also generate patchiness within the community. Sloughing in this case is probably a means of eliminating old reproductive structures and grazer-damaged surface cells, and reducing the likelihood of surface penetration by burrowing organisms. SEM-based energy-dispersive $\mathrm{X}$-ray spectroscopy showed that the relative elemental composition was $50 \%$ carbon, 39\% 


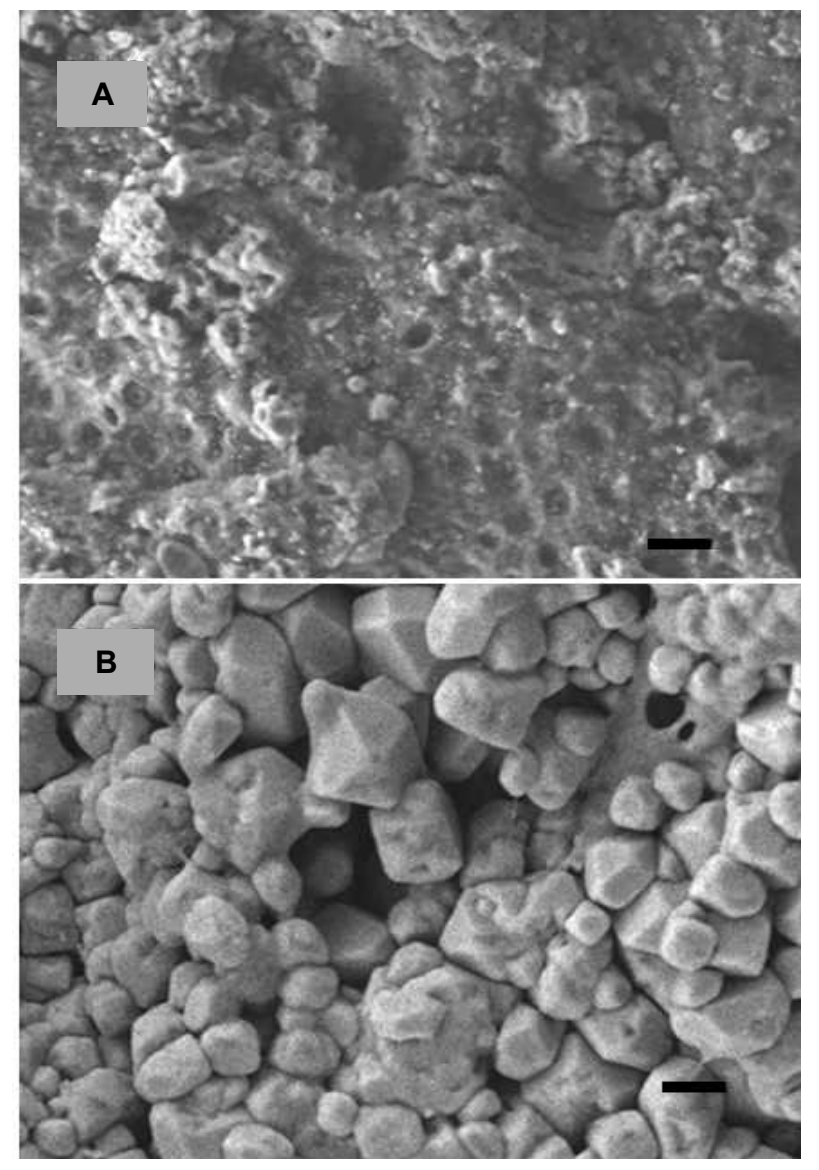

Fig. 4. Tissue of the articulated coralline alga. Scanning electron micrograph of the coralline tissue by 1,000 (A) and 5,000 (B) magnitude. The bars in A and B indicate $10 \mu \mathrm{m}$ and $2 \mu \mathrm{m}$, respectively.

oxygen, $3 \%$ sodium, $2 \%$ chlorine, and $6 \%$ calcium by atomic percentage, or $37 \%$ carbon, $38 \%$ oxygen, $5 \%$ sodium, $5 \%$ chlorine, and $15 \%$ calcium by weight. The major mineral content was calcium carbonate. Calcification by crustose coralline algae is crucial to the formation and maintenance of coral reefs [13]. Coralline algae bind adjacent substrata and provide a calcified tissue barrier against erosion. They also serve as food for grazers - notably parrot fish, urchins, and starfish [1]. Coralline algae provide hard substrata for settlement and metamorphosis in a large diversity of marine invertebrate larvae, including abalone [18]. We found that allelopathic fatty acid substances prevented the settlement or germination of fleshy seaweed spores [10, 14]. Bromomethane released by the articulated coralline alga can eliminate epiphytic organisms, especially microalgae on the surface, and might induce the continuation of coralline flats in marine environments [16]. Crustose coralline algae are thus capable of limiting the local abundance of fleshy seaweed by reducing recruitment success. Furthermore, biomimetic materials derived from the crustose coralline algae, containing antifouling substances, might be developed to protect against the attachment of soft foulants, especially micro- and macroalgae.

\section{Acknowledgments}

This work was supported by the National Research Foundation of Korea Grant funded by the Korean Government (MEST) (NRF-M1A5A1-2012-0029960). We thank the Brain Busan 21 program for graduate scholarship (IJL, JYC).

\section{References}

1. Adey, W. H. 1998. Coral reefs: algal structured and mediated ecosystems in shallow, turbulent, alkaline waters. J Phycol 34, 393-406.

2. Agateuma, Y., Mateuyama, K., Nakata, A., Kawai, T. and Nishikawa, N. 1997. Marine algal succession on coralline flats after removal of sea urchins in Suttsu bay on the Japan Sea coast of Hokkaido, Japan. Nippon Suisan Gakkaishi 63, 672-680.

3. AOAC. 2000. Official Methods of Analysis. Vol. II, 17th ed. Association of Official Analytical Chemists, Washington, D.C., USA.

4. Bird, C. J., Rice, E. L., Murphy, C. A. and Ragan, M. A. 1992. Phylogenetic relationships in the Gracilariales (Rhodophyta) as determined by $18 \mathrm{~S}$ rDNA sequences. Phycologia 31, 510-522.

5. Bittner, L., Payri, C. E., Maneveldt, G. W., Couloux, A., Cruaud, C., de Riviers, B. and Le Gall, L. 2011. Evolutionary history of the Corallinales (Corallinophycidae, Rhodophyta) inferred from nuclear, plastidial and mitochondrial genomes. Mol Phylogenet Evol 61, 697-713.

6. Guiry, M. D. and Guiry, G. M. 2013. AlgaeBase World-wide electronic publication, National University of Ireland, Galway. http://www.algaebase.org; searched on 22 January 2013.

7. Hong, Y. K., Kim, S. D., Polne-Fuller, M. and Gibor, A. 1995. DNA extraction conditions from Porphyra perforata using LiCl. J Appl Phycol 7, 101-107.

8. Johnson, C. R. and Mann, K. H. 1986. The crustose coralline alga, Phymatolithon Foslie, inhibits the overgrowth of seaweeds without relying on herbivores. I Exp Mar Biol Ecol 96, 127-146.

9. Kim, J. H. 2000. Taxonomy of the Corallinales, Rhodophyta, in Korea. Ph.D. dissertation, Seoul National University, Seoul, Korea.

10. Kim, M. J., Choi, J. S., Kang, S. E., Cho, J. Y., Jin, H. J., Chun, B. S. and Hong, Y. K. 2004. Multiple allelopathic ac- 
tivity of the crustose coralline alga Lithophyllum yessoense against settlement and germination of seaweed spores. $J$ Appl Phycol 16, 175-179.

11. Kitamura, H., Kitahara, S. and Koh, H. B. 1993. The induction of larval settlement and metamorphosis of two sea urchins, Pseudocentrotus depressus and Anthocidaris crassispina, by free fatty acids extracted from the coralline red algae Corallina pilulifera. Mar Biol 115, 387-392.

12. Kumar, S., Tamura, K. and Nei, M. 2004. MEGA3: integrated software for molecular evolutionary genetic analysis and sequence alignment. Brief Bioinform 5, 150-163.

13. Littler, M. M. 1972. The crustose Corallinaceae. Oceanogr Mar Biol Annu Rev 10, 311-347.

14. Luyen, Q. H., Cho, J. Y., Choi, J. S., Kang, J. Y., Park, N. G. and Hong, Y. K. 2009. Isolation of algal spore lytic C17 fatty acid from the crustose coralline seaweed Lithophyllum yessoense. J Appl Phycol 21, 423-427.

15. Masaki, T., Fujita, D. and Hagen, N. T. 1984. The surface ultrastructure and epithallium shedding of crustose coralline algae in an Isoyake area of southwestern Hokkaido, Japan. Hydrobiologia 116/117, 218-223.

16. Ohsawa, N., Ogata, Y., Okada, N. and Itoh, N. 2001. Physiological function of bromoperoxidase in the red marine alga, Corallina pilulifera. production of bromoform as an allelochemical and the simultaneous elimination of hydrogen peroxide. Phytochemistry 58, 683-692.

17. Park, S. M., Kang, S. E., Choi, J. S., Cho, J. Y., Yoon, S. J., Ahn, D. H. and Hong, Y. K. 2006. Viability assay of coralline algae using triphenyltetrazolium chloride. Fish Sci 72, 912-914.

18. Roberts, R. D., Kaspar, H. F. and Barker, R. J. 2004. Settlement of abalone larvae in response to five species of coralline algae. J Shellfish Res 23, 975-987.

19. Saito, N. and Nei, M. 1987. The neighbor-joining method: a new method for reconstructing phylogenetic tree. $\mathrm{Mol}$ Biol Evol 4, 406-425.

20. Steneck, R. S. 1986. The ecology of coralline algal crusts: convergent patterns and adaptive strategies. Annu Rev Ecol Syst 17, 273-303.

21. Suzuki, Y., Takabayashi, T., Kawaguchi, T. and Matsunaga, K. 1998. Isolation of an allelophatic substance from the crustose coralline algae, Lithophyllum spp., and its effect on the brown alga, Laminaria religiosa Miyabe (Phaeophyta). J Exp Mar Biol Ecol 225, 69-77.

22. Tokuda, H., Kawashima, S., Ohno, M. and Ogawa, H. 1994. Seaweeds of Japan. Midori Shobo Co., Tokyo, Japan.

23. Whalan, S., Webster, N. S., Negri, A. P. 2012. Crustose coralline algae and a cnidarian neuropeptide trigger larval settlement in two coral reef sponges. PLOS ONE 7, e30386.

\section{초록 : 해조류 무절산호조 혹돌잎의 생물학적 특성 및 조직구조 \\ 강지영 ${ }^{1} \cdot$ lanthe Marie P. Benliro ${ }^{2} \cdot$ 이익준 ${ }^{1}$ 최지영 ${ }^{1} \cdot$ 주진 $^{3} \cdot$ 최유성 $^{4} \cdot$ 황동수 $^{5} \cdot{\text { 홍용기 }\left.\right|^{1,2} \star}^{2}$ \\ (부경대학교 ${ }^{1}$ 생물공학과, ${ }^{2}$ 국제수산과학협동과정, ${ }^{3}$ 경북대학교 응용화학과, ${ }^{4}$ 충남대학교 화학공학과, ${ }^{5}$ 포항 공과대학교 해양대학원)}

연안 암반지역에서 해조류 군락의 소실 즉 백화 혹은 갯녹음현상은 산호조류와 관련성이 있다. 대표적인 무절 산호조의 생물학적 특성을 파악하기 위하여 $18 \mathrm{~S} \mathrm{rDNA}$ 유전자를 분석한 결과 혹돌잎(Lithophyllum) 속에 속하는 것을 확인하였고 그 형태적 특성으로 보아 L. yessoense 종인 것으로 유추된다. Triphenyl tetrazolium chloride로 서 활력을 측정한 결과 12 월에서 2월 사이가 가장 높았으며, 조직 활력을 유지하기 위하여는 $16^{\circ} \mathrm{C}, 16: 8$ 시간 명암 광주기, $30 \mu \mathrm{E} / \mathrm{m}^{2} / \mathrm{s}$ 광도에서 5일간 최적상태를 보였다. 지방산 조성에서는 $\mathrm{EPA}$ 가 가장 많은 고도불포화지방산 으로서 $9.7 \%$ 를 차지하고 있다. 주사형전자현미경에 의한 표면구조를 보면 평균 $3.6 \mu \mathrm{m}$ 직경의 둥근 함몰 분화구 모양을 이루며 그 위에 1.0 내지 $3.7 \mu \mathrm{m}$ 의 비정형 다각형 구조물들이 덮여져 있다. 이 같은 조성과 구조를 바탕으 로 한 생체모방 산호조는 해조류 등에 대한 환경친화적 방오소재로서 활용되어질 수도 있을 것이다. 